\title{
数 \\ Comparison of the effect of particle size on the flotation kinetics of a low-rank coal using air bubbles and oily bubbles
}

\author{
by Y. Liao*, Y. Cao*, C. Liü ${ }^{\dagger}$, Y. Zhao ${ }^{\dagger}$, and G. Zhu ${ }^{\dagger}$
}

\begin{abstract}
Synopsis
The effect of particle size on the flotation kinetics of a low-rank coal was compared using air bubbles and oily bubbles. Five kinetic models were applied to the data from the tests to derive the relationships between the flotation rate constant, the ultimate recovery, and the particle size fraction. The results show that oily bubble flotation (OBF) resulted in a lower ash content and higher combustible recovery than air bubble flotation (ABF), especially for the $-125 \mu \mathrm{m}$ size fraction. It was found that the flotation of a low-rank coal in individual size fractions using air bubbles and oily bubbles can be best described by a first-order model with rectangular distribution of tendency to float and the classical first-order model respectively. OBF yielded higher ultimate combustible and ultimate ash recoveries. The flotation rate constants for OBF were higher in all the models except for the fully mixed reactor model. The ultimate recovery values and modified rate constants first increased and then decreased as the size fraction decreased. The trend of the flotation rate constants as a function of the size fraction was similar in all the models except for the fully mixed reactor model.
\end{abstract}

Keywords

particle size, flotation kinetics, low-rank coal, oily bubble, air bubble.

\section{Introduction}

Froth flotation is a physical-chemical separation method that is widely used in coal beneficiation for the separation of fine coal particles from associated minerals in water slurries. Since the cumulative recovery of a component in the concentrate is proportional to flotation time, the flotation process can be considered as a time-rate recovery process (Emad, Mohammad, and Bahram, 2010). Therefore, the general mathematical flotation models that incorporate both a recovery and a rate function can describe flotation timerecovery profiles.

The kinetics of coal flotation, as a measure of coal recovery as a function of time, have been studied in detail by many researchers. Different kinetic models have been proposed and published in the literature. The order and the rate constant are strongly dependent on the flotation conditions, such as the particle size and size distribution, the bubble concentration, the reagent concentrations, and the operating parameters (Zhang et al., 2013). The particle size has been reported to affect the flotation kinetics to a great extent (Yoon,
Luttrell, and Asmatulu, 2002; Ntengwe and Witika, 2011). Numerous researchers have studied the aspects of flotation kinetics while paying special attention to particle size (Meftuni and Ibrahim, 1997; Rubinstein and Samygin, 1998; Graeme, 2012). However, the effect of particle size on the flotation kinetics of a low-rank coal has been relatively little discussed.

It is difficult to achieve a high yield or combustible matter recovery by flotation of fine low-rank coal, due to the poor hydrophobicity. The presence of polar hydroxyl, carbonyl, and phenol groups and some peroxide-type oxygenated moieties on the surface of low-rank coal decreases the coal hydrophobicity (Xia, Yang, and Liang, 2013). Researchers have investigated many ways to improve the floatability of low-rank coal by using pretreatment prior to flotation and surfactant additions during flotation. Recently, Xia and Yang (2013) designed an oily bubble flotation process using oily bubbles instead of the conventional air bubbles to increase the flotation recovery of low-rank/oxidized coal. The oily bubble flotation $(\mathrm{OBF})$ process yielded a higher combustible matter recovery and lower ash content than the conventional air bubble flotation (ABF) process.

An oily bubble is an air bubble covered with a thin layer of kerosene containing collectors (Liu et al., 2002). The OBF process has been successfully applied in bitumen flotation. A superior performance was noted when using $\mathrm{OBF}$, compared to the use of conventional $\mathrm{ABF}$, when applied to

* National Engineering Research Center of Coal Preparation and Purification, China University of Mining and Technology, Xuzhou, Jiangsu, PR Chinan.

+ School of Chemical Engineering and Technology, China University of Mining and Technology, Xuzhou, Jiangsu, PR China.

(c) The Southern African Institute of Mining and Metallurgy, 2017. ISSN 2225-6253. Paper received Nov. 2015; revised paper received Feb. 2016. 


\section{Comparison of the effect of particle size on the flotation kinetics}

bastnaesite, apatite, dolomite, and quartz (Zhou et al., 2014, 2015). The mechanisms by which oily bubbles improve flotation performance have been studied by various methods. $\mathrm{Su}, \mathrm{Xu}$, and Masliyah (2006) observed that oily bubbles could attain a much higher contact angle and decrease the induction time between bubbles and particles. Zhou et al. (2014) found that the attachment between bastnaesite particles and reactive oily bubbles could be predicted well by the DLVO theory (named after Boris Derjaguin, Lev Landau, Evert Verwey, and Theodoor Overbeek) only within a restricted $\mathrm{pH}$ range, due to the absence of hydrophilic interaction repulsion and chemical interaction forces. In spite of the apparent importance of these observations, very little work has been done on the kinetics of the OBF process.

In the present paper, the effect of particle size fraction on the flotation kinetics of a low-rank coal is compared using conventional $\mathrm{ABF}$ and $\mathrm{OBF}$ Five kinetic models were selected to evaluate the effect of particle size fraction on the kinetic parameters. The flotation performance of $\mathrm{ABF}$ and $\mathrm{OBF}$ was also evaluated on the basis of the selected indices.

\section{Experimental}

\section{Materials}

The coal sample, a sub-bituminous coal, was obtained from the Daliuta coal preparation plant, Shendong Mine Area of China. The moisture content was $8.71 \%$, and the ash content $16.91 \%$ on an air-dry basis. The proximate and ultimate analyses of the sample are given in Table I.

The sample was crushed, ground, and screened into five narrow size fractions: $+500,-500+250,-250+125,-125+74$, and $-74 \mu \mathrm{m}$. Each size fraction was weighed and analysed for ash, then stored in plastic bags until required for flotation tests. Table II shows the particle size and ash distribution of the sample. The yield of the coarse particle size $(+250 \mu \mathrm{m})$

\begin{tabular}{|c|c|c|c|c|c|c|c|c|}
\hline \multicolumn{9}{|c|}{ Table I } \\
\hline \multicolumn{9}{|c|}{$\begin{array}{l}\text { Proximate and ultimate analyses of the coal } \\
\text { sample }\end{array}$} \\
\hline \multicolumn{4}{|c|}{ Proximate analysis (wt $\%, a d)$} & \multicolumn{5}{|c|}{ Ultimate analysis (wt $\%$, daf) } \\
\hline M & $\mathbf{v}$ & A & FC & C & $\mathrm{H}$ & 0 & $\mathbf{N}$ & $\mathbf{s}$ \\
\hline 8.71 & 27.89 & 16.91 & 46.49 & 78.75 & 5.6 & 12.73 & 1.74 & 1.18 \\
\hline
\end{tabular}

Ad = air-dry basis; daf = dry ash-free basis; $M$ = moisture content; $A$ = ash content; $\mathrm{V}=$ volatile matter; $\mathrm{FC}=$ fixed carbon. was $10.44 \%$ with $16.26 \%$ ash. The $-250+74 \mu \mathrm{m}$ size fraction that was suitable for flotation constituted about $55.83 \%$ of the sample. The fine $(-74 \mu \mathrm{m})$ particles accounted for $33.73 \%$ of the total. It is important to note that the ash content of the $-74 \mu \mathrm{m}$ size fraction was high, at about $20.26 \%$.

Kerosene was used as the collector and 2-octanol as the frother.

\section{Apparatus}

An experimental apparatus was designed for the OBF, consisting of a flotation cell, an electrical heating jacket, a four-necked flask, a calibrated flow meter, a thermocouple, and a syringe (Figure 1). Kerosene was injected into the flask via the syringe. The flask was heated in the electrical jacket to a temperature of about $240^{\circ} \mathrm{C}$. The thermocouple was used to measure the flask's temperature. When kerosene was injected into the flask, it instantly vapourized due to the high temperature, and the air stream containing the kerosene vapour was sucked into the pipes connected with the flotation cell. The air flow rate was regulated by a control valve, dependent upon the readings of the calibrated flow meter. By this process, the vapourized kerosene was cooled, and huge amounts of kerosene drops were created. When the air stream entered the flotation cell, fine bubbles were generated by the cell rotor device. As the kerosene drops collide with the air bubbles, since both streams are hydrophobic, the air bubbles become coated with kerosene. This mechanism is enhanced by the molecular movement of the kerosene drops, enabling dispersion of the drops and coverage of the bubble surface as the oily bubbles are formed.

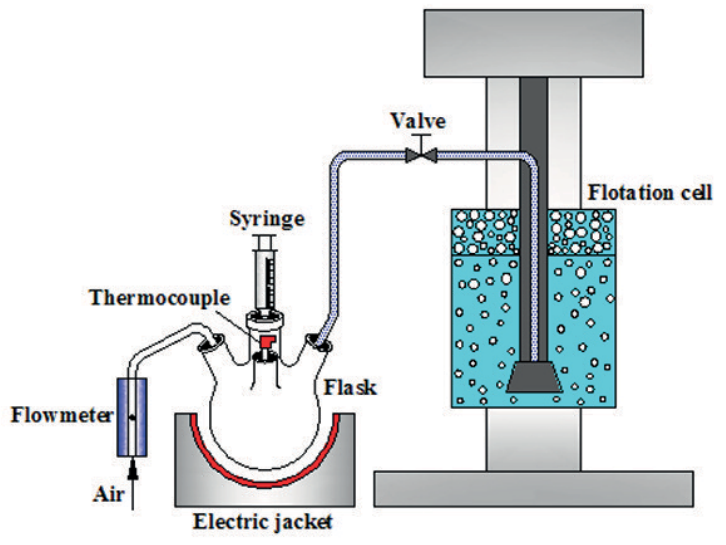

Figure 1-Experimental apparatus for oily bubble flotation test work

\section{Table II}

Size and ash distribution of the coal sample

\begin{tabular}{|c|c|c|c|c|c|c|}
\hline \multirow[t]{2}{*}{ Size fraction, $\mu \mathrm{m}$} & \multirow[t]{2}{*}{ Yield, \% } & \multirow[t]{2}{*}{ Ash, \% } & \multicolumn{2}{|c|}{ Cumulative oversize, \% } & \multicolumn{2}{|c|}{ Cumulative undersize, \% } \\
\hline & & & Yield & Ash & Yield & Ash \\
\hline $\begin{array}{l}+500 \\
-500+250 \\
-250+125 \\
-125+74 \\
-74 \\
\text { Total }\end{array}$ & $\begin{array}{c}2.71 \\
7.73 \\
29.12 \\
26.71 \\
33.73 \\
100.00\end{array}$ & $\begin{array}{c}18.9 \\
15.33 \\
15.02 \\
15.43 \\
20.26 \\
17.03\end{array}$ & $\begin{array}{c}2.71 \\
10.44 \\
39.56 \\
66.27 \\
100.00\end{array}$ & $\begin{array}{c}18.9 \\
16.26 \\
15.35 \\
15.38 \\
17.03\end{array}$ & $\begin{array}{c}100 \\
97.29 \\
89.56 \\
60.44 \\
33.73\end{array}$ & $\begin{array}{l}17.03 \\
16.97 \\
17.12 \\
18.13 \\
20.26\end{array}$ \\
\hline
\end{tabular}




\section{Comparison of the effect of particle size on the flotation kinetics}

\section{Methods}

The flotation tests were conducted on size fractions of +500 , $-500+250,-250+125,-125+74$, and $-74 \mu \mathrm{m}$ using oily bubbles and conventional air bubbles. All the tests were conducted in a $1.5 \mathrm{~L}$ XFD flotation cell using $120 \mathrm{~g}$ of coal at a pulp density of $7.4 \%$ solids, with a kerosene (collector) dosage of $5 \mathrm{~kg} / \mathrm{t}$ (kilograms reagent per ton coal) and $0.5 \mathrm{~kg} / \mathrm{t} 2$-octanol (frother). The impeller speed was 1800 $\mathrm{r} / \mathrm{min}$ and the air flow rate was set at $2 \mathrm{~L} / \mathrm{min}$.

For the conventional flotation tests, the slurry was first agitated in the flotation cell for 3 minutes. The requisite amount of kerosene and 2-octanol was then added and the slurry was conditioned for an additional 3 minutes. Flotation was started by introducing air. Froth samples were collected after $0.5,1,2,3$, and 5 minutes of flotation.

A similar procedure was conducted for the OBF tests, except that only 2-octanol was added before introducing air. The flask was preheated to $240^{\circ} \mathrm{C}$ and a requisite amount of kerosene was held in the syringe. When the valve was opened, the kerosene was injected into the flask. The kerosene instantly vapourized and passed through the tube along with the air to the flotation cell.

The flotation products were filtered, dried, weighed, and analysed for ash. The combustible matter and ash recoveries were calculated from the following equations (Gupta, Banerjee, and Mishra, 2009; Liao et al., 2015):

$$
\begin{aligned}
& \varepsilon_{C}(\%)=\left[W_{C}\left(100-A_{C}\right) / W_{F}\left(100-A_{F}\right)\right] \times 100 \\
& \varepsilon_{A}(\%)=\left(W_{C} A_{C} / W_{F} A_{F}\right) \times 100 \\
& S E(\%)=\varepsilon_{C}-\varepsilon_{A}
\end{aligned}
$$

where $\varepsilon_{C}$ is the combustible recovery, $\varepsilon_{A}$ the ash recovery, $S E$ the separation efficiency, $W_{C}$ the weight of the concentrate (\%), $W_{F}$ the weight of the feed (\%), $A_{C}$ the ash content of the concentrate (\%), and $A_{F}$ is the ash content of the feed (\%).

In this work, five kinetic flotation models (Chaves and Ruiz, 2009; Zhang et al., 2013) were selected to study the effects of particle size on low-rank coal flotation using oily bubbles and conventional air bubbles, as shown in Table III. The combustible and ash recoveries after $0.5,1,2,3$, and 5 minutes of flotation time were fitted to the five kinetic models. Origin 8.0 graphing and analysis software was used to simulate the flotation rate constant $(k)$, the ultimate recovery $\left(\varepsilon_{\infty}\right)$, and the correlation coefficient $\left(R^{2}\right)$ based on the Levenberg-Marquardt (LM) algorithm.

\section{Results and discussion}

\section{Effect of particle size on flotation performance}

The influence of the particle size on the concentrate ash and combustible content is illustrated in Figure 2. For both ABF and $\mathrm{OBF}$, the coarse size fraction $(+250 \mu \mathrm{m})$ yielded the lowest ash content and combustible recovery. The combustible recovery from the intermediate size fraction $(-250+74 \mu \mathrm{m})$ was much higher than that from the coarse and the fine $(-74 \mu \mathrm{m})$ size fractions. The fine size fraction yielded an intermediate combustible recovery, but the ash content was highest. Moreover, it is obvious that $\mathrm{OBF}$ is superior to $\mathrm{ABF}$ for all size fractions in terms of lower ash content and higher combustible recovery. For the $-125+$ $74 \mu \mathrm{m}$ size fraction, ABF has potential to give a product with $11.10 \%$ ash content and $66.47 \%$ combustible recovery after 5 minutes of flotation. With $\mathrm{OBF}$, the product ash content can be reduced further to $9.37 \%$ with $93.63 \%$ combustible recovery after 5 minutes of flotation. Similar results have been reported for numerous mineral flotation processes (Peng and Li, 1991; Xia and Yang, 2013; Su, Xu, and Masliyah, 2006). This may be attributed to the fact that with oily bubbles the contact angle is increased and the induction time between bubbles and particles decreased.

The effect of particle size on flotation performance in $\mathrm{ABF}$ and $\mathrm{OBF}$ is further compared in Figure 3, where the cumulative values in the final concentrate after 5 minutes of flotation is taken as the measure. The ash content in concentrate for $\mathrm{OBF}$ is lower than that for $\mathrm{ABF}$ at different size fractions, particularly for the $-74 \mu \mathrm{m}$ size fraction. At the same time, OBF results in a higher combustible recovery, ash recovery, and separation efficiency for all the size fractions, in particular the $-125 \mu \mathrm{m}$ size fraction. The ash content of the concentrate increases with decreasing particle size in both $\mathrm{ABF}$ and $\mathrm{OBF}$, while the combustible recovery, ash recovery, and separation efficiency first increase and then decrease. The difference in ash content for both $\mathrm{ABF}$ and $\mathrm{OBF}$ becomes more pronounced as the particle size decreases. A similar trend can be seen for ash recovery. It is interesting to note that for both the combustible recovery and ash recovery, the difference between $\mathrm{ABF}$ and $\mathrm{OBF}$ first increases and then

\section{Table III}

\section{Flotation kinetic models}

\begin{tabular}{|l|c|c|}
\hline No. & Model & Formula \\
\hline 1 & Classical first-order model & $\varepsilon(t)=\varepsilon_{\infty}\left[1-\exp \left(-k_{1} t\right)\right]$ \\
3 & $\begin{array}{c}\text { First-order model with rectangular } \\
\text { distribution of tendency to float }\end{array}$ & $(t)=\varepsilon_{\infty}\left\{1-\frac{1}{k_{2} t}\left[1-\exp \left(-k_{2} t\right)\right]\right\}$ \\
4 & Fully mixed reactor model & $\varepsilon(t)=\varepsilon_{\infty}\left(1-\frac{1}{1+t / k_{3}}\right)$ \\
5 & $\begin{array}{c}\text { Second-order kinetic model } \\
\text { Second-order model with rectangular } \\
\text { distribution of tendency to float }\end{array}$ & $\varepsilon(t)=\frac{\varepsilon_{\infty}^{2} k_{4} t}{1+\varepsilon_{\infty} k_{4} t}$ \\
&
\end{tabular}

$\varepsilon(t)=$ fractional recovery at time $t, \varepsilon_{\infty}=$ fractional ultimate recovery, $k=$ flotation rate constant

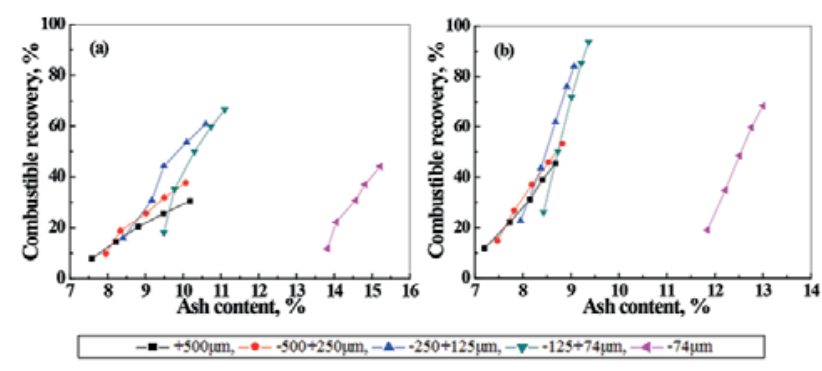

Figure 2-Effect of size fraction on flotation performance: (a) air bubble flotation; (b) oily bubble flotation 


\section{Comparison of the effect of particle size on the flotation kinetics}
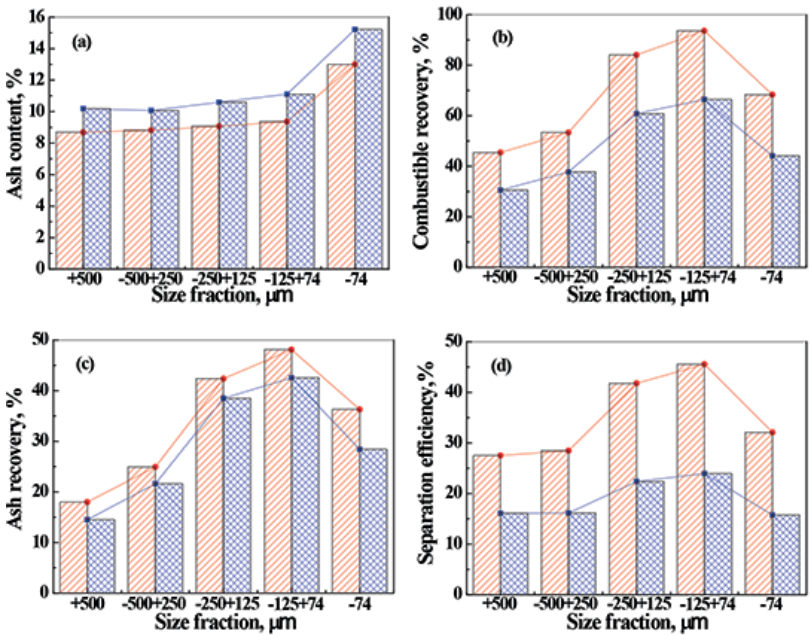

Air bubble, 20 Oily bubble $-m-$ Air bubble, $-\bullet-$ Oily bubble

Figure 3-Comparison of flotation performance between air bubble and oily bubble flotation: (a) ash content; (b) combustible recovery; (c) ash recovery; (d) separation efficiency

decreases with decreasing particle size, with the greatest difference in the $-125+74 \mu \mathrm{m}$ size fraction. OBF therefore shows better flotation performance compared to $\mathrm{ABF}$, especially for the $-125 \mu \mathrm{m}$ size fraction.

\section{Effect of particle size on flotation kinetics}

The combustible recovery, ash recovery, and separation efficiency for different size fractions as a function of flotation time are shown in Figures 4-6. These figures clearly illustrate that for all the size fractions, combustible recovery, ash recovery, and separation efficiency increase with increasing flotation time, with the rate of increase becoming less with increasing time. It is also observed that for a given flotation time, combustible recovery, ash recovery, and separation efficiency first increase and then decrease with decreasing particle size, with the maximum values being for the $-125+74 \mu \mathrm{m}$ size fraction. Moreover, the combustible recovery, ash recovery, and separation efficiency are higher for OBF than for $\mathrm{ABF}$ at the same flotation time for all the size fractions, which indicates that $\mathrm{OBF}$ has better kinetics.

The test results related to the combustible and ash recoveries versus flotation time at different size fractions for
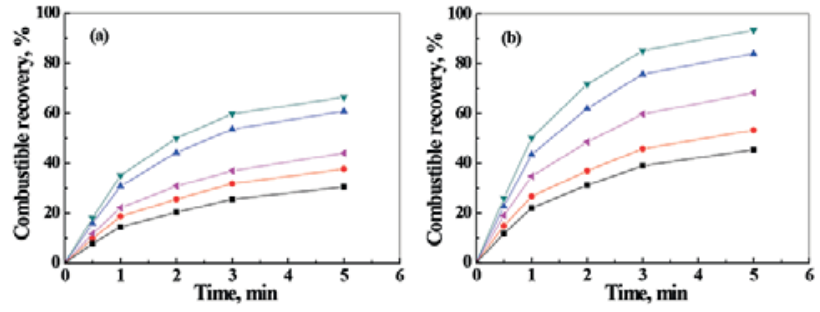

$-7-+500 \mu \mathrm{m},-\bullet--500+250 \mathrm{\mu m},-\Lambda--250+125 \mathrm{\mu m},-\mathrm{\gamma}--125+74 \mu \mathrm{m},-4--74 \mathrm{\mu m}$

Figure 4-Combustible recovery to concentrate for different size fractions as a function of flotation time: (a) air bubble flotation; (b) oily bubble flotation
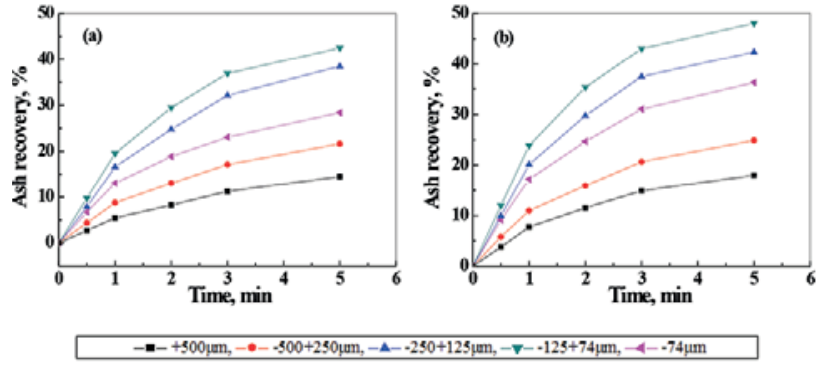

Figure 5-Ash recovery to concentrate in different size fractions as a function of flotation time: (a) air bubble flotation; (b) oily bubble flotation
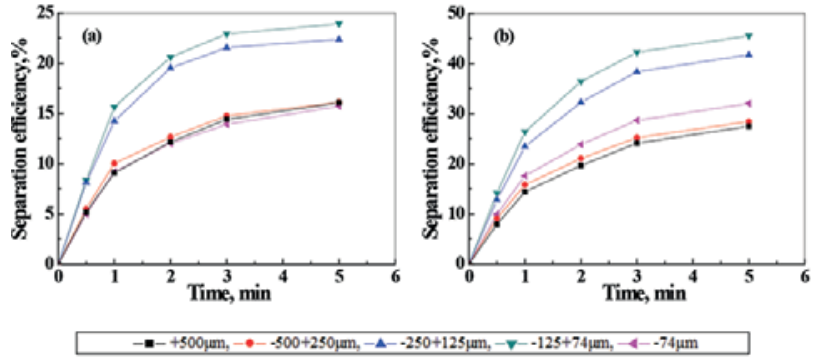

Figure 6-Separation efficiency in different size fractions as a function of flotation time: (a) air bubble flotation; (b) oily bubble flotation

both $\mathrm{ABF}$ and $\mathrm{OBF}$ were fitted to the five flotation kinetic models using Origin 8.0 analysis software. The fractional ultimate recovery $\left(\varepsilon_{\infty}\right)$, flotation rate constant $(k)$, and the correlation coefficient $\left(R^{2}\right)$ are given in Tables IV and V.

Table IV

Fitted results of air bubbe flotation by different size fractions

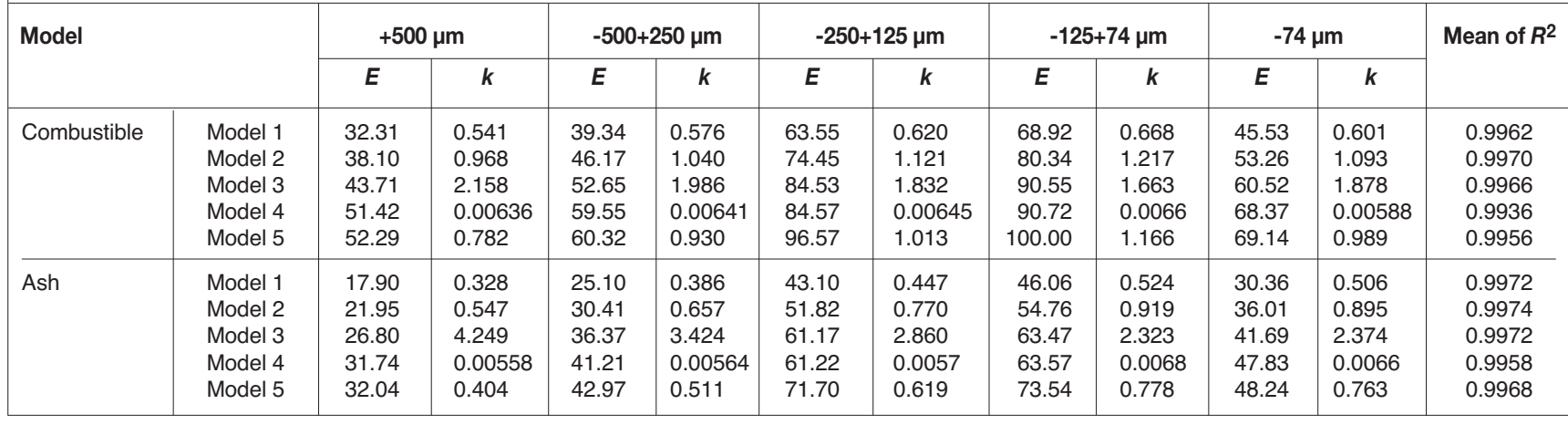




\section{Comparison of the effect of particle size on the flotation kinetics}

Table $\mathrm{V}$

Fitted results of oily bubbe flotation by different size fractions

\begin{tabular}{|c|c|c|c|c|c|c|c|c|c|c|c|c|}
\hline \multicolumn{2}{|l|}{ Model } & \multicolumn{2}{|c|}{$+500 \mu \mathrm{m}$} & \multicolumn{2}{|c|}{$-500+250 \mu \mathrm{m}$} & \multicolumn{2}{|c|}{$-250+125 \mu \mathrm{m}$} & \multicolumn{2}{|c|}{$-125+74 \mu \mathrm{m}$} & \multicolumn{2}{|c|}{$-74 \mu \mathrm{m}$} & \multirow[t]{2}{*}{ Mean of $R^{2}$} \\
\hline & & $E$ & $k$ & $E$ & $k$ & $E$ & $k$ & $E$ & $k$ & $E$ & $k$ & \\
\hline $\begin{array}{l}\text { Combustible } \\
\text { recovery }\end{array}$ & $\begin{array}{l}\text { Model } 1 \\
\text { Model } 2 \\
\text { Model } 3 \\
\text { Model } 4 \\
\text { Model } 5\end{array}$ & $\begin{array}{l}47.90 \\
56.37 \\
64.46 \\
65.80 \\
74.00\end{array}$ & $\begin{array}{l}0.567 \\
1.017 \\
2.044 \\
0.0071 \\
0.900\end{array}$ & $\begin{array}{l}55.30 \\
64.65 \\
73.31 \\
73.75 \\
83.65\end{array}$ & $\begin{array}{l}0.605 \\
1.100 \\
1.856 \\
0.0072 \\
1.003\end{array}$ & $\begin{array}{c}87.81 \\
100.00 \\
100.00 \\
100.00 \\
100.00\end{array}$ & $\begin{array}{l}0.643 \\
1.191 \\
1.284 \\
0.0079 \\
1.450\end{array}$ & $\begin{array}{r}97.01 \\
100.00 \\
100.00 \\
100.00 \\
100.00\end{array}$ & $\begin{array}{l}0.689 \\
1.373 \\
1.285 \\
0.0104 \\
1.722\end{array}$ & $\begin{array}{c}70.83 \\
82.73 \\
93.61 \\
93.86 \\
100.00\end{array}$ & $\begin{array}{l}0.624 \\
1.137 \\
1.791 \\
0.00591 \\
1.195\end{array}$ & $\begin{array}{l}0.9971 \\
0.9898 \\
0.9720 \\
0.9847 \\
0.9317\end{array}$ \\
\hline $\begin{array}{l}\text { Ash } \\
\text { recovery }\end{array}$ & $\begin{array}{l}\text { Model } 1 \\
\text { Model } 2 \\
\text { Model } 3 \\
\text { Model } 4 \\
\text { Model } 5\end{array}$ & $\begin{array}{l}20.12 \\
24.18 \\
28.51 \\
34.28 \\
35.39\end{array}$ & $\begin{array}{l}0.445 \\
0.768 \\
2.862 \\
0.00716 \\
0.555\end{array}$ & $\begin{array}{l}27.38 \\
32.70 \\
38.20 \\
42.34 \\
44.47\end{array}$ & $\begin{array}{l}0.468 \\
0.816 \\
2.646 \\
0.00725 \\
0.678\end{array}$ & $\begin{array}{l}45.56 \\
53.99 \\
62.24 \\
62.38 \\
71.85\end{array}$ & $\begin{array}{l}0.550 \\
0.971 \\
2.178 \\
0.00732 \\
0.835\end{array}$ & $\begin{array}{l}50.90 \\
59.89 \\
68.35 \\
68.50 \\
78.38\end{array}$ & $\begin{array}{l}0.602 \\
1.076 \\
1.928 \\
0.0075 \\
0.955\end{array}$ & $\begin{array}{l}38.61 \\
45.61 \\
52.42 \\
55.60 \\
60.39\end{array}$ & $\begin{array}{l}0.544 \\
0.968 \\
2.167 \\
0.0073 \\
0.843\end{array}$ & $\begin{array}{l}0.9975 \\
0.9973 \\
0.9962 \\
0.9950 \\
0.9953\end{array}$ \\
\hline
\end{tabular}

As evident from the results in Table IV, in general, the mean correlation coefficients $\left(R^{2}\right)$ for the five kinetic models are greater than 0.9900 , which indicates that all the models give an excellent fit to the experimental data for ABF. The highest mean correlation coefficients for combustible and ash recoveries are 0.9970 and 0.9974 respectively, which are both obtained by Model 2 . As shown in Table V, the mean correlation coefficients of all kinetic models fitted to combustible recovery by OBF are lower, except for Model 1 , with a mean $R^{2}$ greater than 0.9900 . However, the mean correlation coefficients of the five kinetic models fitted to ash recoveries of OBF are all higher than 0.9950, with Model 1 having the highest value of 0.9975 . Therefore, we conclude that the flotation of this low-rank coal in individual size fraction using air bubbles and oily bubbles can be described by the first-order model with rectangular distribution of tendency to float and classical first-order model, respectively.

As evident from Tables IV and V, the ultimate recovery values increase from Model 1 to Model 5. The ultimate recovery values for $\mathrm{OBF}$ are higher than those for $\mathrm{ABF}$ in a given size fraction for both combustible and ash recovery calculations. At the same time, the flotation rate constants for $\mathrm{OBF}$ are higher than those for $\mathrm{ABF}$ at a given size fraction for all the models except Model 3. Moreover, the size fraction strongly influences the ultimate recovery value and flotation rate constant. The trend of the ultimate recovery values as functions of the size fraction are similar to the test data, as shown in Figures 4 and 5, respectively. The flotation rate constant also first increases and then decreases as the size fraction decreases in all of the models except Model 3. Similar findings have been reported in investigations of the kinetics of waste coal flotation and reverse flotation of lignite (Sokolovic, Stanojlovic, and Markovic, 2012; Zhang et al., 2013).

$\mathrm{Xu}$ (1998) suggested a modified rate constant, $K$, the product of $\varepsilon_{\infty}$ and $k$, and proposed a quantity called the selectivity index (SI) to compare results of flotation kinetics experiments. $K$ can be written as:

$$
K=\varepsilon_{\infty} \times k
$$

The modified rate constants were used to define a new quantity, viz., the selectivity index $(S I)$ or the relative modified rate constant of combustible matter $\left(K_{C}\right)$ over that of ash $\left(K_{A}\right)$. The selectivity index is calculated by the following equation (Natarajan and Nirdosh, 2009):
$S I=K_{C} / K_{A}$

Modified rate constants and selectivity indices were used to compare the selectivity between $\mathrm{ABF}$ and $\mathrm{OBF}$. Table VI presents the calculated values of modified rate constant and selectivity index $(S I)$. As seen, the modified rate constants $K_{C}$ and $K_{A}$ at first increase and then decrease with decreasing size fraction in both $\mathrm{ABF}$ and $\mathrm{OBF}$, with the maximum $K_{C}$ and $K_{A}$ obtained in the intermediate size fraction $(-125+$ $74 \mu \mathrm{m})$. However, the selectivity index decreases as the size fraction decreases in both cases, with the minimum $S I$ obtained for the fine size fraction of $-74 \mu \mathrm{m}$. These results can be used to explain the trend of flotation performance as a function of the size fraction, as previously discussed.

\section{Conclusions}

Flotation tests on a low-rank coal were carried out to investigate the differences in performance and kinetics between air bubble flotation (ABF) and oily bubble flotation $(\mathrm{OBF})$. The model fitting was performed using five flotation kinetic models to estimate the relationships between the flotation rate constant, the ultimate recovery, and the particle size fraction. The conclusions drawn from this study are as follows.

(1) $\mathrm{OBF}$ is superior to $\mathrm{ABF}$ in terms of ash content and combustible recovery, especially for the $-125 \mathrm{~m}$ size fraction

(2) The first-order model with rectangular distribution of tendency to float provides the best fit to the experimental data for $\mathrm{ABF}$, and the classical firstorder model the best fit for OBF. OBF yields higher ultimate recovery values for combustible matter and lower ash recovery values. The flotation rate constants for OBF are higher in all the models except the fully mixed reactor model

(3) Size fraction strongly affects the flotation kinetics of low-rank coal. The ultimate recovery values and modified rate constants first increase and then decrease as the particle size decreases. The trend of the flotation rate constants as functions of the size fraction is similar in all the models except the fully mixed reactor model.

\section{Recommendations}

Further research should be conducted on the oily bubble 


\section{Comparison of the effect of particle size on the flotation kinetics}

Table VI

Calculated values of modified rate constants and selectivity index (SI)

\begin{tabular}{|c|c|c|c|c|c|c|c|c|c|c|}
\hline \multirow[t]{2}{*}{ Parameter } & \multicolumn{5}{|c|}{ Air bubble } & \multicolumn{5}{|c|}{ Oily bubble } \\
\hline & $+500 \mu \mathrm{m}$ & $-500+250 \mu \mathrm{m}$ & $-250+125 \mu \mathrm{m}$ & $-125+74 \mu \mathrm{m}$ & $-74 \mu \mathrm{m}$ & $+500 \mu \mathrm{m}$ & $-500+250 \mu \mathrm{m}$ & $-250+125 \mu \mathrm{m}$ & $-125+74 \mu \mathrm{m}$ & $-74 \mu \mathrm{m}$ \\
\hline$K_{C}$ & 36.8790 & 48.0250 & 83.4368 & 97.8018 & 58.2047 & 27.1375 & 33.4316 & 56.4967 & 66.8384 & 44.1900 \\
\hline$K_{A}$ & 12.0112 & 19.9811 & 39.9263 & 50.3450 & 32.2301 & 8.9635 & 12.8134 & 25.0503 & 30.6379 & 20.9957 \\
\hline SI & 3.0704 & 2.4035 & 2.0898 & 1.9426 & 1.8059 & 3.0275 & 2.6091 & 2.2553 & 2.1816 & 2.1047 \\
\hline
\end{tabular}

concept. For a larger scale application of the oily bubble concept, the energy consumption for high-temperature heating has to be taken into account in a comprehensive economic analysis. Collectors with lower boiling points can decrease the energy required for high-temperature heating so as to further reduce the costs associated with oily bubble flotation. These collectors need to be considered in future research to increase the economic advantage of the oily bubble concept. In addition, it is important to find a more economical and efficient way to produce the oily bubbles. The properties of the oily bubbles and the air bubbles, such as zeta potential, induction time, and bubble size, should be further investigated in order to explain the advantages of oily bubble flotation and the flotation mechanism.

\section{Notation}

$A_{C} \quad$ Ash content of the concentrate, $\%$

$A_{F} \quad$ Ash content of the feed, \%

$k \quad$ Flotation rate constant, minute- 1

$K \quad$ Modified rate constant, $\% /$ minute

$K_{A} \quad$ Modified rate constant of combustible matter, \%/minute

$K_{C} \quad$ Modified rate constant of ash matter, \%/minute

$R^{2} \quad$ Correlation coefficient

$S E \quad$ Separation efficiency, \%

SI Selectivity index

$W_{C} \quad$ Weight of concentrate, $\mathrm{g}$

$W_{F} \quad$ Weight of feed, $g$

$\varepsilon(t)$ Fractional recovery at time $t, \%$

$\varepsilon_{A} \quad$ Ash recovery, \%

$\varepsilon_{C} \quad$ Combustible recovery, $\%$

$\varepsilon \quad$ Ultimate recovery, $\%$

\section{Acknowledgements}

This research was supported by the Fundamental Research Funds for the Central Universities (Grant no. 2015QNB16).

\section{References}

Chaves, A.P. and RuIz, A.S. 2009. Considerations on the kinetics of froth flotation of ultrafine coal contained in tailings. International Journal of Coal Preparation and Utilization, vol. 29. pp. 289-297.

Emad, A., Mohammad, K., and Bahram, R. 2010. A study on the effect of particle size on coal flotation kinetics using fuzzy logic. Expert Systems with Applications, vol. 37. pp. 5201-5207.

Graeme, J.J. 2012. The effect of surface liberation and particle size on flotation rate constants. Minerals Engineering, vol. 36-38. pp. 132-137.

GuPTA, A.K., BAnerJeE, P.K., and Mishra, A. 2009. Influence of chemical parameters on selectivity and recovery of fine coal through flotation. International Journal of Mineral Processing, vol. 92, no. 1. pp. 1-6.
Liao, Y.F., Cao, Y.J., Huang, S.M., He, J., Zhang, X.B., LI, S.L., and Shao, S.G. 2015. Water carrying property of flotation frothers and its effect on fine coal flotation. International Journal of Coal Preparation and Utilization, vol. 35 , no. 2. pp. 88-98.

LiU, J., MAк, T., Zноu, Z., and Xu, Z. 2002. Fundamental study of reactive oilybubble flotation. Minerals Engineering, vol. 15. pp. 667-676.

Meftuni, Y. and IвRAHim, S. 1997. Effect of the hydrophobic fraction and particle size in the collectorless column flotation kinetics. Colloids and Surfaces A: Physicochemical and Engineering Aspects, vol. 121. pp. 9-13.

NATARAjAN, R. and NiRDosh, I. 2009. Effect of molecular structure on the kinetics of flotation of a Canadian nickel ore by $\mathrm{N}$-arylhydroxamic acids. International Journal of Mineral Processing, vol. 93. pp. 284-288.

NTENGWE, F. and WiTiKA, L.K. 2011. Optimization of the operating density and particle size distribution of the cyclone overflow to enhance the recovery of the flotation of copper sulphide and oxide minerals. Journal of the Southern African Institute of Mining and Metallurgy, vol. 111, no. 4. pp. 295-300.

Peng, F.F. and Li, H.R. 1991. Oil-coated air bubble flotation to improve coal flotation rate and recovery. Preprint no. 91-77:1. Society for Mining, Metallurgy, and Exploration, Inc., Littleton, CO.

Rubinstein, J.B. and SAmygin, V.D. 1998. Effect of particle and bubble size on flotation kinetics. Recent Advances in Coal Processing, no. 2. pp. 51-80.

SoKolovic, J.M., STANojLovic, R.D., and Markovic, Z.S. 2012. The effects of pretreatment on the flotation kinetics of waste coal. International Journal of Coal Preparation and Utilization, vol. 32. pp. 130-142.

Su, L., Xu, Z., and MasLIYAH, J. 2006. Role of oily bubbles in enhancing bitumen flotation. Minerals Engineering, vol. 19. pp. 641-650.

XIA, W.C., YANG, J.G., and LiAng, C. 2013. A short review of improvement in flotation of low rank/oxidized coals by pretreatments. Powder Technology, vol. 237. pp. 1-8.

XIA, W.C. and YANG, J.G. 2013. Experiment design of oily bubble in oxidized coal flotation. Gospodarka Surowcami Mineralnymi, vol. 29, no. 4. pp. $129-135$.

Xu, M.Q. 1998. Modified flotation rate constant and selectivity index. Minerals Engineering, vol. 11, no. 3. pp. 271-278.

Yoon, R.H., LuttrelL, G.H., and Asmatulu, R. 2002. Extending the upper particle size limit for coal flotation. Journal of the South African Institute of Mining and Metallurgy, vol. 102, no. 7. pp. 411-415.

ZHANG, H.J., LIU, J.T., CAO, Y.J., and WANG, Y.T. 2013. Effects of particle size on lignite reverse flotation kinetics in the presence of sodium chloride. Powder Technology, vol. 246. pp. 658-663.

Zhou, F., Wang, L.X., Xu, Z.H., Liu, Q.X., and CHI, R.A. 2014. Interaction of reactive oily bubble in flotation of bastnaesite. Journal of Rare Earths, vol. 32, no. 8. pp. 772-778.

Zhou, F., Wang, L.X., Xu, Z.H., Liu, Q.X., and CHI, R.A. 2015. Reactive oily bubble technology for flotation of apatite, dolomite and quartz. International Journal of Mineral Processing, vol. 134. pp. 74-81. 